\title{
Gradual change in international organisations: agency theory and historical institutionalism
}

Hanrieder, Tine (2014) Gradual change in international organisations: agency theory and historical institutionalism. Politics, 34 (4). 324 - 333. ISSN 0263-3957

\section{Accepted manuscript}

\section{Introduction}

In their 1998 review article, James March and Johan Olsen alerted IR institutionalists to pay more attention to the sources and dynamics of 'inefficient history' in international institutions (March and Olsen 1998). According to the authors, history is 'inefficient' where institutions do not linearly adapt to changing state preferences and power constellations due to endogenous dynamics. In the meantime IO researchers have taken up this challenge, yet mostly the roots of historical inefficiency have been attributed to the bureaucratic organs of IOs (Barnett and Finnemore, 2004; Weaver, 2008). This research note, by contrast, draws attention to the fact that even state-driven politics is not linear in IOs due to locked-in formal rules and endogenous sources of power. Following up on works which suggest that historical institutionalism (HI) offers valuable concepts for explaining institutional inertia and gradual rather than abrupt change in global politics (Fioretos, 2011; Farrell and Newman, 2010; Chwieroth, 2013), I carve out under what conditions different types of gradual change are most likely to occur. I suggest that $\mathrm{HI}$ is particularly well-equipped to capture change in constellations where states can exploit their institutional veto powers to block attempts at IO reform. These are widespread constellations in IOs, where principles such as one state, one vote, grant smaller states disproportionate votes or seats on IO governing bodies. Pressure for change by great powers that are relatively disadvantaged by formal decision rules therefore does not lead to linear adaptation, but often results in complex and gradual modes of change such as 'layering' and 'drift.'

Linear, deliberate reform, by contrast, is the established domain of principal-agent (PA) analysis. I will argue in the following section that PA concepts are best applicable where reformers control both, material powers and the formal decision-making process. The subsequent section then presents how HI notions of gradual change can help to fill the gap left by PA analysis. Finally, I propose an explanatory 
heuristic linking types of IO reform coalitions to types of change in IOs. I conclude with some remarks on methodology.

\section{Principal-agent analysis and the challenge of unilateral influence in IOs}

Since international organizations (IO) have re-entered institutionalist scholarship in International Relations (IR, see Abbott and Snidal, 1998), a burgeoning literature seeks to explain the relative autonomy and the conditions of change in IOs. Much of this research has been conducted within the principal-agent framework, focusing on the question of whether and how states (the principals) control change in IOs (the agents). While this framing has spurred a productive research agenda, like any research paradigm it has also attracted criticism. One line of criticism questions the assumption that IOs are to be conceived as rational 'agents'. Constructivists have argued, for example, that their internal predispositions make IO bureaucracies culture-driven rather than goal-oriented agents (Barnett and Finnemore, 2004; Weaver, 2008). But also from a rationalist perspective, the idea that IOs are coherent agents capable of goal-oriented action is often unrealistic. Organizational fragmentation and bureaucratic politics undermine corporate agency in IOs (Graham, 2013; Hanrieder, 2013; Kassim and Menon, 2003). Where IOs are not responsive to external incentives, PA mechanisms of control are rendered ineffective (Graham, 2013). Hence, challenges to IO agency are important challenges to PA explanations, too.

While these are important limitations, it is another line of criticism that this research note aims to contribute to: namely, that the principal-side of agency theory rests on equally problematic assumptions. PA analysis rests on a formalistic conception of IO politics that prioritizes the formal decision-making process over other forms of influence in IOs. In fact, the legalist premise that member states govern international organizations via the PA contract is fundamental to PA research (Nielson and Tierney, 2003). In the PA view, states delegate authority to and re-contract with IOs to realize joint preferences via the agent (Hawkins et al., 2006). This emphasis on the formal contract is challenged in particular by students of unilateral, and often informal, channels of state influence in IOs (Urpelainen, 2012, p. 707): 
States are not a board of directors that first resolve their disputes, then write a legally binding contract to delegate, and finally discipline the bureaucrat. In addition to pursuing their interests by bargaining over the delegation contract, states can exert unilateral influence on policy implementation by the bureaucrat.

The possibility of unilateral influence is a common and important feature in IO politics. Where member states disagree on how to work through IOs, formal re-contracting is not the dominant method of change. Rather, states will seek to influence IOs individually, and often informally. Randall Stone argues, for example, that great powers will find ways to shape IO behavior outside formal channels, for example by biasing policy implementation through their engagement in administrative organs (Stone, 2011; Urpelainen, 2012).

The possibility of unilateral influence challenges the analytical utility of PA concepts in two main respects. For one, unilateral influence collapses the dichotomous principal-versus-agent conceptualization of IO change, i.e. the idea that IO change is either based on the principals' 'common agency' or, in case of disagreement among principals, on autonomous bureaucratic agency and rentseeking (Copelovitch, 2010). Stone rather claims that zones of bureaucratic discretion offer precisely the margin within which powerful states can influence IO activities across the PA divide (Stone, 2011). Policy implementation in IOs therefore tends to be biased in the favor of the great powers that circumvent collective decision-making through their privileged influence on IO bureaucrats (see also Urpelainen, 2012). Furthermore, the possibility of unilateral influence problematizes the legalist notion of state power endorsed by PA theorists. The PA approach is premised on 'a strictly formal notion of power, which flows through authoritative rule structures specified in constitutions, articles of agreement, or charters' (Nielson and Tierney, 2003: 251; cf. Lyne, Nielson and Tierney, 2006). This does not mean that PA scholars deny power politics and great power influence. However, the underlying expectation is that major powers will be able to dominate the bargaining process and thereby the collective principal, and hence that the PA contract remains the adequate shortcut for assessing influence in IOs. What 'IO unilateralism' suggests, by contrast, is that material and formal power should be treated separately instead of lumped together with in the concept of 'member state principal'. Both sources of power may 
be causally related as when material power can be translated into formal influence, but often there remains a considerably discrepancy.

Indeed, great powers are relatively disadvantaged by formal IO rules. The United Nations organizations that follow the one state, one vote principle, grant weaker states disproportionate formal powers. But also the governing bodies of the Bretton Woods institutions favor weaker states in relative terms, despite the weighted voting system (Stone, 2011, p. 18). These rules can be circumvented by informal means or by exerting bargaining power in member state negotiations. But in many cases they also constrain the impact of great power influence on IO change, by enabling small states to block certain changes. These considerations underline that the complex interplay between rules and power within international institutions is an ongoing theoretical challenge for IR institutionalists (Stone, 2009, p. 48-49; see Barnett and Duvall, 2005). To shed light on this blind spot of PA analysis, IR scholars can draw on insights from historical institutionalism (see Fioretos, 2011). This research tradition in fact starts from the observation of an institutional friction between formal rules and material power.

\section{Gradual change in the shadow of reform blockades}

The very fact that states turn to unilateral and informal strategies of influence indicates that change in international organizations is not always controlled by a coherent actor or coalition. Yet the absence of negotiated reform is not the same as non-change. This observation is central to recent historical institutionalist works on gradual modes of institutional change. Mostly orientated to explaining change in national economic policies, the works of Kathleen Thelen and colleagues transcend the classic historical institutionalist focus on stability. These authors rather argue that 'path dependent' institutional reproduction becomes itself transformative over time. Importantly, this dynamism is an implication of the coercive and power-laden nature of institutions, i.e. the dual insight that formal institutions confer power on certain actors while being dependent on the influx of resources from the institutional environment (Hall and Taylor, 1996; Streeck and Thelen, 2005). Hence on the one hand, the actors privileged by specific institutions seek to capitalize on their formal positions and defend their privileges, 
but on the other hand powerful actors will emerge that challenge the institution from the outside. Challengers that are disadvantaged by institutional structures will seek ways to modify institutions even if formal revision is blocked by institutional veto players (Hacker, 2004; Mahoney and Thelen, 2010; Streeck and Thelen, 2005; Thelen, 1999).

This dynamism led historical institutionalists to identify patterns of gradual change that fall outside the category of all-out 'revision' (Hacker, 2004) or 'displacement' (Streeck and Thelen, 2005) - and thus also beyond the idea of principal-induced reform in IOs. I will focus on the two most pertinent patterns of gradual institutional transformation, namely 'layering' and 'drift'.

Both layering and drift describe incremental reconfigurations of institutions that are not centrally controlled, but emerge out of the interplay between institutional constraints and exogenous challenges. First, layering describes a pattern of change whereby new institutional elements are introduced on top of or alongside existing ones (Mahoney and Thelen, 2010, p. 15). Layering occurs where reformers can or do not alter core institutions, for example because these are protected by veto players or by legal lockin, but instead graft additional components upon the institutional core. A prominent example of layering is the introduction of a private pension system alongside an existing and entrenched public pension system (Streeck and Thelen, 2005, p. 23). But also in IOs new 'layers' are often grafted on established institutions that are not removed, but rather supplemented (or eventually supplanted) by the new section 3 (redundant) elements. The International Labour Organization (ILO), for example, has reacted to the growing ratification gap regarding its numerous conventions and recommendations with the overarching 1998 Declaration on Fundamental Principles and Rights at Work. The Declaration and its distinct monitoring and review mechanisms now interact with establihed ILO law, thus altering the overall normative output of the organization (Helfer, 2006: 709-711).Secondly, drift refers to a mode of change whereby formally stable institutions alter their impact due to insufficient updating. Changes in the institution's environment such as demographic or economic changes that are not reflected in the operation of the institutions thus mean that the impact of institutions erodes even though they are formally stable (Mahoney and Thelen, 2010, p. 16). Revisionists can therefore undermine an institution simply by vetoing reform attempts at adapting it to evolving circumstances. The combination of endogenous non- 
decisions ensured by the institutional power of revisionists and of exogenous changes can thereby lead to an institution's marginalization that is not manifested in specific events or reforms, but nevertheless consequential for the operation of the institution. In this vein, Jacob Hacker argues in his analysis of the US welfare that where policies are not adapted to encompass new social risks, the seeming stability of the welfare state actually amounts to its hollowing out (Hacker, 2004). Regulatory drift is also common in international politics where institutions are often slow at adapting to changes in their regulatory environment - technological changes such as the development of new weaponry, changes in the natural environment not covered by environmental regimes, or social and economic changes. For example, Alexander Betts argues that the global refugee regime is failing to extend protection to new categories of refugees that flee their states for reasons other than targeted individual persecution by governments (Betts, 2013) - a classic case of regulatory erosion or drift.

These categories of gradual change help to conceptualize modes of institutional change in world politics that lie between all-out reform or total inertia (see also Chwieroth, 2013). Beyond this descriptive valueadded, the following section proposes an explanatory heuristic of institutional constellations and the PAbased and HI-based types of change associated with them.

\section{Coalitions and modes of change in IOs}

We have seen that for HI analysis to be relevant, formal institutional power is not to be reducible to exogenous or 'material' power. Only where institutions confer independent powers on their participants can they endogenously constrain the pathway of institutional change. Yet indeed, the tension between endogenous organizational powers and exogenous 'material' powers does not only mark domestic, but also international politics. On the one hand, IOs are growing older, but do not always adapt to changing power constellations - the United Nations Security Council prominently illustrates such inertia and lockin. On the other hand, in most IOs smaller states are overrepresented by design (Stone, 2011). Therefore, politics in IOs is shaped by two separate dimensions of state power: formal authority as granted via voting rights or seats in executive organs, and material powers that are largely independent from these 
institutional privileges. The fungibility of such exogenous power resources depends on their relevance to the IO's activities: money and donations will be most important in service providing IOs such as UNICEF, military forces matter in particular to security organizations such as NATO, and market size is a crucial asset in trade organizations such as the WTO. States bring these material powers to bear on the process of IO change, but they have to do so within the constraints posed by existing rules. Hence endogenously, smaller states can be in a position to block reform attempts or they may be able to set reform agendas that are undesired by the great powers.

The varied configurations that can result from the interaction between formal and material powers in IOs can be mapped in a simple heuristic of different types of reform coalitions. Reform coalitions here refer to groups of like-minded member states that seek to alter IOs according to their preferences. Evidently, in real-world reform processes IO bureaucrats and non-state actors are also part of reform coalitions (see below), yet like in PA analysis we shall focus on the most decisive level of member state powers and preferences - just that the power dimension is made more complex in here. The heuristic differentiates institutional constellations depending on whether reform coalitions control organizational vetoes (formal power), crucial external resources (material power), or both. This distinction allows us to situate the typical domains of PA and HI analysis and opens analytical space for HI-inspired conjectures about typical patterns of gradual transformations in IOs (see figure 1).

\section{- Figure 1 about here -}

The figure shows two constellations where material and formal powers are congruent (upper left and lower right box), i.e. where reform advocats control both sources of power, or none. These are classic domains of PA analysis. A constellation of congruence between material and formal power (upper left) maps a situation where a state coalition striving for reform can formally decide on and materially back up the desired reform agenda. This is the basic PA constellation where deliberate change is to be expected. It is mostly to be found in organizations with weighted voting systems such as the Bretton Woods institutions. For example, the World Bank's 'greening of aid' over the 1990s is a well-known case of principal-induced reform. As Daniel Nielson and Michael Tierney have argued, the Bank significantly altered its lending practices after its main principals called for the incorporation of 
environmental principles into its development projects. These appeals were backed up by material incentives such as the withholding of financial contributions (Nielson and Tierney, 2003). Hence, the main donors' control of both decisional power and material resources led to a directed change within the Bank. There are manifold comparable cases of steered reform in IOs through treaty reform or concerted policy change. A prominent example of negotiated change is the transition from the General Agreement on Tariffs and Trade (GATT) to the World Trade Organization (WTO) in 1994. Notably, with the 'single undertaking' principle states here bought into the entire WTO 'package' rather than picking and choosing among sub-regimes, and thereby deliberately prevented fragmentation and layering within the WTO. Another recent case of concerted reform is the (re-)authorization of the International Monetary Fund in the context of the 2008/9 world financial crisis, which was backed up by a major replenishment of IMF funds.

Evidently, coherent reforms also take place in IOs that do not have weighted voting systems such as those organizations where the one state, one vote principle applies. But these organizations have a greater potential for a clash of coalitions with different power resources. In one possible constellation the reform coalition has formal control without material backup (lower left): Where a coalition of 'small' states commands a formal majority in IO bodies and decides on a reform, the backlash of the decision may be that great powers diminish their material support, or even turn to other organizations instead. This weakens the IO relative to other organizations, and thus results in a relative loss of impact within its organizational field. In analogy to the notion of regulatory drift outlined above - as referring to the changing impact of rules (Hacker, 2004) - such developments can be labeled instances of organizational drift, i.e. a changed impact of IOs on their domain of activity.

IO drift is a major tendency in an international environment that offers states myriad opportunities for forum shopping (see Alter and Meunier, 2009). In an extreme form, drift can entail a full-blown exit of member states, which happened for example during the United Nations Educational, Cultural and Scientific Organization's (UNESCO's) struggle over a New World Information Communication Order (NWICO) in the 1970s. The endorsement of the NWICO agenda was pushed by a coalition of developing countries but led to fierce ideological confrontations and moved the US and the United 
Kingdom not only to withhold financial contributions, but in fact to temporarily quit membership during the 1980s (Singh, 2011, p. 110-120). Although not entailing all-out exit, similar developments took place in the World Health Organization (WHO), for example after World Health Assembly (WHA) endorsed the Model List of Essential Medicines in the late 1970s. This motivated the United States to withhold its contributions and to force a policy of zero real growth on the organization - i.e. a constant decline in regular budgetary contributions. The US and other donor states increasingly turned to other venues for pursuing global health policies, for example the World Bank or the public-private partnerships that were founded at the turn of the millennium (Lee, 2009, p. 89-122). Instances of IO drift raise important questions regarding the institutional choices made by states (Jupille, Mattli and Snidal, 2013). Yet they also raise the question of how institutions change where power diffuses. HI-inspired analyses of IO drift could thus investigate how drift feeds back on the 'source institutions' - for example whether they are redeployed to new purposes, hollowed out, or used as strategic venues of institutional conflict (see Raustiala and Victor, 2004).

The opposite constellation is that powerful states sponsor change in IOs but cannot overturn internal veto players, i.e. they hold material power without formal control (upper right). This constellation is likely to induce layering as a dominant reform strategy. Where an all-out reform is unavailable due to formal lock-in or decisional blockades, materially powerful reform coalitions can opt for circumventing established structures. They do so by grafting additional elements on top of the organizational core. An illustrative example of this dynamic is the WHO's positioning vis-à-vis the post-WWII population control movement. As the Vatican and catholic member states opposed initiatives to engage in population planning at the WHO, by the 1960s proponents of population planning turned to creating a 'special' WHO program for human reproduction. This program was relatively independent from core WHO decision-making structures and operational procedures, mainly thanks to its financing through voluntary donations (Finkle and Crane, 1976). This case exemplifies a more general trend in many United Nations organizations that are increasingly funded with 'extrabudgetary' contributions by affluent donors. Extrabudgetary donations are usually earmarked for specific IO units and programs and thus often reflect unilateral preferences. This also applies to the World Bank that today operates more than 1.000 so-called trust funds that are unilaterally funded and only loosely integrated with core 
structures of the Bank (Distler, 2012). Such additions of new organizational layers not only render IOs more complex, but can considerably transform them. Over time, the layered elements may replace or render irrelevant core institutions without that these have been formally replaced (see Chwieroth, 2013). Finally, the lower right box where neither endogenous nor exogenous resources are mobilized for IO $\underline{\text { reform }}$ is also a common and far from irrelevant constellation. This situation where rules and policies are not challenged by any state coalition only looks like non-change at first glance. Here IO researchers need to look at factors beyond member state coalitions to identify drivers of change. PA analysis here offers a fruitful hypothesis, suggesting that in the absence of state-led reform, bureaucratic agency becomes decisive for IO change - either in the form of routine adaptation within the delegated mandate, or in the form of rent-seeking and mission creep (Copelovitch, 2010). This is not to say that IO bureaucracies only influence IO change where states are inactive (see Johnson, 2013). Bureaucrats are usually part of reform coalitions, collaborating with like-minded states across IO boundaries (see Hanrieder, 2013). However, the heuristic outlined in here contributes to specifying under what institutional conditions their role should be of particular relevance.

\section{Conclusion}

This research note has offered a rationale for identifying different constellations among IO member states that should trigger different modes of change in IOs. Evidently, the types of change outlined herein will take different shapes in different contexts and need to be investigated empirically. Modes of change may also interact and follow, if not trigger each other. The above heuristic can thus only provide a starting point, albeit hopefully a productive one, for examining institutional dynamics of change in international organizations. Research along these lines will need to take into account that the concepts introduced above are not fully specified hypotheses to be tested, but rather thinking tools to be refined through empirical analysis (see van der Heijden, 2011, 2013). These tools must be applied to generate 
distinct insights about institutional dynamic in global politics, a political sphere which increasingly resembles 'HI conditions' rather than 'PA conditions':

For as IOs grow older and thereby also more resilient (Ingram and Torfason, 2010, p. 598), and as the international order grows more institutionalized, complex institutional dynamics will increasingly shape the evolution of IOs. Theories of gradual institutional change can make an important contribution here in that they conceptualize how sedimented privileges interact with external challenges to bring about distinct modes of institutional change. HI-inspired research can deepen our understanding of institutional development in an IO landscape that is growing more complex by the day. The long-term dynamics arising from different modes of change, their intended and unintended effects, as well as their typical sequences and interactions amongst different pathways, should be central topics in future research on IO change.

\section{Acknowledgements}

I thank Christian Kreuder-Sonnen, Andreas Kruck, Xenia Lanzendörfer, Bernhard Zangl and the three anonymous reviewers of Politics for their constructive comments.

\section{About the author}

Dr. Tine Hanrieder is an assistant professor at LMU Munich. She researches on international organization, normative discourse and on international health politics. Her work has been published in journals including International Theory and the Journal of International Relations and Development. Email: tine.hanrieder@gsi.uni-muenchen.de. 


\section{References}

Abbott, K. W., and Snidal, D. (1998) 'Why States act Through Formal International Organizations', The Journal of Conflict Resolution, 42(1), pp. 3-32.

Alter, K. J., and Meunier, S. (2009) 'The Politics of International Regime Complexity', Perspectives on Politics, 7(1), pp. 13-24.

Barnett, M., and Duvall, R. (eds.) (2005) Power in Global Governance, Cambridge: Cambridge University Press.

Barnett, M., and Finnemore, M. (2004) Rules for the World. International Organizations in Global Politics, Ithaca: Cornell University Press.

Betts, A. (2013) Survival Migration: Failed Governance and the Crisis of Displacement. Ithaca: Cornell University Press.

Chwieroth, J. M. (2013) 'Controlling Capital: The International Monetary Fund and Transformative Incremental Change From Within International Organisations', New Political Economy, advance online (29 May).

Copelovitch, M. S. (2010) 'Master or Servant? Common Agency and the Political Economy of IMF Lending', International Studies Quarterly, 54(1), pp. 49-77.

Distler, L. (2012) 'Institutional Fragmentation - a Means to Obtain Leadership? The World Bank in Global Health', paper presented at the Annual Convention of the International Studies Association, 1-4 April, San Diego, CA, USA.

Farrell, H. and A. L. Newman (2010): 'Introduction: Making Global Markets: Historical Institutionalism in International Political Economy', Review of International Political Economy 17(4), pp. 609-638. Finkle, J. L. and Crane, B. (1976) 'The World Health Organization and the Population Issue: Organizational Values in the United Nations', Population and Development Review, 2(3/4), pp. 367 393.

Fioretos, O. (2011) 'Historical Institutionalism in International Relations', International Organization 65(2), pp. 367-399. 
Graham, E. (2013) 'International Organizations as Collective Agents: Fragmentation and the Limits of Principal Control at the World Health Organization', European Journal of International Relations, online first (30 May), pp. 1-25.

Hacker, J. S. (2004) 'Privatizing Risk Without Privatizing the Welfare State: The Hidden Politics of Social Policy Retrenchment in the United States', American Political Science Review, 98(2), pp. $243-260$.

Hall, P. A., and Taylor, R. C. R. (1996) 'Political Science and the Three New Institutionalisms', Political Studies, 44(5), pp. 936-957.

Hanrieder, T. (2013) 'Local Orders in International Organizations: The World Health Organization's Global Programme on AIDS', Journal of International Relations and Development online first (19 April), pp. 1-22.

Hawkins, D. G., Lake, D. A., Nielson, D. L., and Tierney, M. J. (2006) 'Delegation Under Anarchy: States, International Organizations, and Principal-Agent Theory’, in D. G. Hawkins, D. A. Lake, D. L. Nielson and M. J. Tierney (eds.) Delegation and Agency in International Organizations, Cambridge: Cambridge University Press, pp. 3-38.

Helfer, L. R. (2006) 'Understanding Change in International Organizations: Globalization and Innovation in the ILO', Vanderbilt Law Review 59(3): 649-726.

Ingram, P., and Torfason, M. T. (2010) 'Organizing the In-Between: The Population Dynamics of Network-Weaving Organizations in the Global Interstate Network', Administrative Science Quarterly, 55(4), pp. 577-605.

Johnson, T. (2013) 'Institutional Design and Bureaucrats' Impact on Political Control'. Journal of Politics 75(1), pp. 183-197.

Jupille, J., Mattli, W., and Snidal, D. (2013) Institutional Choice in Global Commerce, Cambridge: Cambridge University Press.

Kassim, H., and Menon, A. (2003) 'The Principal-Agent Approach and the Study of the European Union: Promise Unfulfilled?', Journal of European Public Policy, 10(1), pp. 121-139.

Lee, K. (2009) World Health Organisation, London: Routledge. 
Lyne, M. M., Nielson, D. L., and Tierney, M. J. (2006) 'Who Delegates? Alternative Models of Principals in Development Aid', in D. G. Hawkins, D. A. Lake, D. L. Nielson and M. J. Tierney (eds.) Delegation and Agency in International Organizations, Cambridge: Cambridge University Press, pp. 41-76.

Mahoney, J., and Thelen, K. (2010) ‘A Theory of Gradual Institutional Change’, in J. Mahoney and K. Thelen (eds.) Explaining Institutional Change: Ambiguity, Agency, and Power, Cambridge: Cambridge University Press, pp. 1-37.

March, J. G., and Olsen, J. P. (1998) 'The Institutional Dynamics of International Political Orders', International Organization, 52(4), pp. 943-969.

Nielson, D. L., and Tierney, M. J. (2003) 'Delegation to International Organizations: Agency Theory and World Bank Environmental Reform', International Organization, 57(2), pp. 241-276.

Raustiala, K., and Victor, D. G. (2004) 'The Regime Complex for Plant Genetic Resources', International Organization, 58(2), pp. 277-309.

Singh, J. P. (2011) United Nations Educational, Scientific and Cultural Organization, London, New York: Routledge.

Stone, R. W. (2009) 'Institutions, Power, and Interdependence', in H. V. Milner and A. Moravcsik (eds.) Power, Interdependence, and Nonstate Actors in World Politics, Princeton, NJ: Princeton University Press, pp. 31-49.

Stone, R. W. (2011) Controlling Institutions: International Organizations and the Global Economy, Cambridge, New York, Melbourne: Cambridge University Press.

Streeck, W., and Thelen, K. (2005) 'Introduction: Institutional Change in Advanced Political Economies', in W. Streeck and K. Thelen (eds.) Beyond Continuity: Institutional Change in Advanced Political Economies, Oxford: Oxford University Press, pp. 3-39.

Thelen, K. (1999) 'Historical Institutionalism in Comparative Politics', Annual Review of Political Science, 2, pp. 369-404.

Thelen, K. (2004) How Institutions Evolve: The Political Economy of Skills in Germany, Britain, the United States, and Japan, Cambridge: Cambridge University Press. 
Urpelainen, J. (2012) 'Unilateral Influence on International Bureaucrats: An International Delegation

Problem', Journal of Conflict Resolution, 56(4), pp. 704-735.

van der Heijden, J. (2011) 'Institutional Layering: A Review of the Use of the Concept', Politics 31(1),

pp. $9-18$.

van der Heijden, J. (2013) 'Different But Equally Plausible Narratives of Policy Transformation: A Plea

For Theoretical Pluralism', International Political Science Review 34(1), pp. 57-73.

Weaver, C. (2008) Hypocrisy Trap. The World Bank and the Poverty of Reform, Princeton, NJ: Princeton

University Press.

i Beyond layering and drift, most HI taxonomies of institutional change also comprise the modes of 'displacement' and 'conversion' (Mahoney and Thelen, 2010: 19). 'Displacement' designates abrupt and deliberate rather than gradual change, and thus can be subsumed under the category of negotiated reform covered by PA research (see section 3). Conversion describes reinterpretations of rules over time and thus the insight that different actors deploy rules differently (see Thelen, 2004). In this article I treat this insight as a constant feature of institutional development rather than a variable to be explained (see on this aspect Mahoney and Thelen, 2010: 19). 